\title{
Monika Inków
}

University of Zielona Góra

e-mail:m.inkow@wez.uz.zgora.pl

ORCID: 0000-0002-3179-9404

\section{MEASURING INNOVATION MATURITY - LITERATURE REVIEW ON INNOVATION MATURITY MODELS}

\author{
POMIAR DOJRZAŁOŚCI INNOWACYJNEJ - \\ PRZEGLĄD LITERATURY DOTYCZĄCEJ \\ MODELI DOJRZALOŚCI INNOWACYJNEJ
}

DOI: 10.15611/ie.2019.1.02

JEL Classification: O30

Summary: In recent years it has noticed that innovation and innovativeness have become the basis for the success of not only individual business entities but entire regions and economies. What is more, there have been opinions in the literature that individual innovations are no longer a guarantee of survival for an organization, but such a guarantee is rather the capacity for continuous innovation. Therefore the organization's ability to transform resources in favour of the organization - the innovation capability - is decisive, while the ability to use resources appropriately, including innovation capabilities, is referred to as innovation maturity. In this article the author decided to introduce the essence of innovation maturity models as a tool for measuring innovation maturity. These models are a tool for assessing the level of innovation maturity of an organization. It is worth adding that maturity models originate from the Capability Maturity Model developed by the Software Engineering Institute.

Keywords: innovation capability, innovation maturity, innovation maturity models.

Streszczenie: W ostatnich latach autorzy zauważyli, że innowacje i innowacyjność stały się podstawą sukcesu nie tylko pojedynczych podmiotów gospodarczych, ale całych regionów czy gospodarek. Co więcej, w literaturze pojawiły się głosy, że pojedyncze innowacje nie są już gwarancją przetrwania organizacji, jest nią raczej zdolność do wprowadzania innowacji w sposób ciągły. Decydujące znaczenie ma zatem zdolność organizacji do przekształcania zasobów na korzyść organizacji - zdolność innowacyjna, natomiast umiejętność odpowiedniego wykorzystania zasobów, w tym zdolności innowacyjnych, określana jest mianem dojrzałości innowacyjnej. W niniejszym artykule autorka postanowiła przybliżyć istotę modeli dojrzałości innowacyjnej będących narzędziem oceny poziomu dojrzałości innowacyjnej organizacji, biorących początek od Capability Maturity Model, który został opracowany przez Software Engineering Institute.

Słowa kluczowe: zdolność innowacyjna, dojrzałość innowacyjna, modele dojrzałości innowacyjnej. 


\section{Introduction}

In recent years, scholars have noticed that innovation and innovativeness have become the basis for the success of business entities, as well as for regions and entire economies. It is worth adding that more and more authors point out that the survival of organizations in present times does not depend on single innovations, but rather on the ability to innovate continuously (e.g. Saunila, 2016; Blommerde and Lynch, 2016).

Teece's theory of dynamic capabilities is an extension of the resource-based view and an attempt to answer the question of how enterprises can achieve competitive advantage operating in a changing environment (Teece, Pisano, and Shuen, 1997; Teece, 2007; Stawasz, 2014).

In light of the assumptions of the dynamic capabilities concept, internal resources and competencies are insufficient to achieve a competitive advantage. They only create the innovative potential necessary to create innovative solutions (Brzeziński, 2001; Stanisławski, 2013). This potential affects the innovation capability, but it is not the only factor influencing innovative changes introduced in organizations. The ability to transform resources is decisive for the creation of innovation, because the dynamic development of the environment requires the organization's ability to adapt to the changing conditions, including market opportunities and technologies (e.g. Stawasz, 2012, 2014; Stanisławski, 2013; Borch and Madsen, 2007, Liao, Kickul, and Ha, 2009; Batko, 2017).

Innovation capability thus influences the innovative results of the organization as well as its competitive advantage, but this relation is the result of the development of dynamic capabilities (Wang, Ahmed, 2007; Zhang, Garrett-Jones, and Szeto, 2013). In addition, it is worth noting that without sufficiently high dynamic capabilities, the organization may encounter difficulties when developing new innovative solutions (e.g. Stawasz, 2014; Stanisławski, 2013; Zahra and George, 2002), and thus find it difficult to achieve a higher level of innovative maturity, which is measured by innovation maturity models.

The purpose of this article is to present the essence of the innovation maturity models which are used as a tool to measure of the innovation maturity of organizations.

\section{Innovation capability and the innovation maturity of enterprises}

An organization's innovation capability is currently of interest to an increasing number of researchers (e.g. Lawson and Samson, 2001; Patalas-Maliszewska and Kłos, 2013; Stawasz, 2014; Breznik and Luhovnik, 2014), and it is defined, for example, as "the ability to continuously transform knowledge and ideas into new products, processes and systems for the benefit of the firm and its stakeholders"(Lawson and Samson, 2001, p. 384), as "the potential of an organisation to innovate (Neely, Filippini, Forza, Vinelli and Hii, 2001; O'Connor and Ayers, 2005), as "the assembling of the 
'right ingredients' for innovation in an organisation" (Hamel, 2006), as "a highly integrated ability to shape and manage multilateral skills and resources" (Stawasz, 2014, p. 99), or as "the ability to formulate and implement innovation strategies and it is associated with the capability to create, enlarge and modify resources employed for innovation in order to develop new products, services, processes and/or markets" (Dodgson, Gann, and Salter, 2008). It is worth noting that, according to many authors, having high innovation capability is an important source of company performance (e.g. Calantoe Cavusgill, and Zhao, 2002; Tsai and Tsai, 2010; Chow and Gong, 2010; Aziz and Omar, 2013), innovation performance (e.g. Mir, Casadesus, and Petnji, 2016) and the opportunity to achieve a competitive advantage (e.g. Guan and Ma, 2003; Basterretxea and Martinez, 2012; Zaleśna, 2013; Żołnierski, 2005).

It should be noted that innovation capacity is particularly important for enterprises operating in an environment of rapid change (Teece, Pisano, Shuen, 1997; Eisenhardt and Martin, 2000; Breznik and Lahovnik, 2014), in particular in such an environment in which companies from the IT industry operate. Birchall and Tovstiga (2005) even believe that innovation capability is the most important capability that enterprises have, which Schumpeter has already written about, recognizing the value of continuous innovation (Schumpeter, 1934). The research carried out by Breznik and Lahovnik (2014) is also worth mentioning; these authors distinguished six dynamic capabilities, (managerial capability; marketing capability; technological capability; R\&D capability; innovation capability; and human resources capability), which contribute to achieving a competitive advantage by IT companies, indicating innovation capability as the key one, defining it as the strategic strength of IT companies (Breznik and Lahovnik, 2014).

The ability to properly use existing resources, including dynamic innovation capabilities (Lachniewicz, Łuczka, and Stawasz, 2010, p. 6; Gajdzik, 2012; Niedzielski, 2005; Corsic and Neau, 2015), recognized by researchers as a key element in the development of innovation (Lawson and Samson, 2001; Hogan, Soutar, McColl-Kennedy, Sweeney, 2011; Zaleśna, 2013; Pomykalski, 2001, PatalasMaliszewska and Kłos, 2013, Hurmelinna-Laukkanen Sainio, and Jauhiainen, 2008) is referred to as innovation maturity. Therefore it can be concluded that the innovation maturity of an organization can be perceived through the prism of its dynamic capabilities, including dynamic innovation capability. An organization's greater dynamic innovation capability is reflected in the growing number of innovative solutions presented in response to changes in the organization's environment, leading to an increase in the level of innovation maturity of that organization (Stawasz, 2012; Stanisławski, 2013).

However, innovation maturity models derived from dynamic capability maturity models can be used to measure the level of innovation maturity (e.g. Wendler, 2012; Esterhuizen, Schutte, and du Toit, 2011). Researchers express a growing interest in these models (e.g. Corsic and Neau, 2015; Esterhuizen et al. 2011; Mirkowska, 2010).

Innovation maturity models allow to assess the level of innovation maturity of an organization, and they also indicate in which areas it is worth making changes 
so that the organization can achieve a higher level of innovation maturity and a competitive advantage.

\section{Innovation maturity models}

As Wendler (2012) notes, maturity models are used to "define a set of levels or stages, describing the development of the examined object in a simplified way. These stages should be sequential in nature and represent a hierarchical progression. Furthermore, they should be closely connected to organizational structures and activities [...] stages or levels which measure the completeness of the analysed objects via different sets of (multi-dimensional) criteria" (Wendler, 2012, p. 1319). The CMM model developed in 1986 by the Software Engineering Institute is seen as the source of maturity models. Researchers wanting to develop a framework for assessing the maturity levels of software processes have developed the so-called Capability Maturity Model (CMM) (Paulk, Curtis, Chrissis, and Weber, 1993).

It is worth mentioning that currently maturity models are gaining more and more attention in many areas (Röglinger, Pöppelbuß, Becker, 2012), for example: inventory management (Niemi, Huiskonen, and Karkkainen, 2009), supply chain management (Lockamy and McCormack, 2004), new product development (NPD) (Fraser, Moultrie, and Gregory, 2002), R\&D projects (Berg, Leinonen, Leivo, and Pihlajamaa, 2002), project management (Cooke-Davies and Arzymano, 2003; Ibbs, and Kwak 2002) quality management (Morsal, Ismail, and Osman, 2009) industrial maintenance (Macchi and Fumagalli, 2013), product development (Farrukh, Fraser, and Gregory, 2003), logistics (Battista and Schiraldi, 2013), collaboration (Campos, Chalmeta, Grangel, and Poler, 2013), environmental concerns (Ormazábal and Sarriegi, 2013), and finally innovation capability (Table 1). Table 1 presents the results of a systematic literature review on the existing models of innovation maturity.

Table 1. Identified innovation maturity models

\begin{tabular}{|l|l|l|}
\hline \multicolumn{1}{|c|}{ Author } & \multicolumn{1}{|c|}{ Model name } & \multicolumn{1}{c|}{ Model characteristics } \\
\hline \multicolumn{1}{|c|}{1} & \multicolumn{1}{|c|}{2} & \multicolumn{1}{c|}{3} \\
\hline $\begin{array}{l}\text { Tata Consultancy } \\
\text { Services Ltd } \\
\text { Narayana, 2005 }\end{array}$ & $\begin{array}{l}\text { The Innovation } \\
\text { Maturity Model }\end{array}$ & $\begin{array}{l}\text { This model highlights the maturity levels based on the } \\
\text { Capability Maturity Model. }\end{array}$ \\
\hline PRTM, 2007 & $\begin{array}{l}\text { PRTM Innovation } \\
\text { Maturity Model }\end{array}$ & $\begin{array}{l}\text { The model consists of four levels of innovation maturity } \\
\text { that have not been named, where each level of the model } \\
\text { is characterized by a set of representative management } \\
\text { practices in four areas (vision and strategy, insights, } \\
\text { management, organization). }\end{array}$ \\
\hline Essmann, 2009 & $\begin{array}{l}\text { Innovation } \\
\text { Capability Maturity } \\
\text { Model }\end{array}$ & $\begin{array}{l}\text { The model consists of a total of five levels of maturity, } \\
1,3 \text { and 5 and two intermediate levels between them, i.e. } \\
\text { between 1 and 3 and 3 and 5. The distinguished maturity } \\
\text { levels are: }\end{array}$ \\
\hline
\end{tabular}


Table 1, cont.

\begin{tabular}{|c|c|c|}
\hline 1 & 2 & 3 \\
\hline & & $\begin{array}{l}\text { 1) Ad hoc and limited. } \\
\text { 3) Formalization and predictability. } \\
\text { 5) Integration, synergy and autonomy. } \\
\text { It is a three-dimensional model, covering elements from } \\
\text { the following areas: innovation maturity, organisational } \\
\text { construct and innovation capability construct. }\end{array}$ \\
\hline $\begin{array}{l}\text { Think for } \\
\text { a Change, } 2009\end{array}$ & $\begin{array}{l}\text { IM2-Innovation } \\
\text { Maturity Model }\end{array}$ & $\begin{array}{l}\text { This model has six levels of innovation maturity: } \\
\text { Innovation deficient, Innovation Structure, Innovation } \\
\text { processes, Innovation standards, Innovation optimized, } \\
\text { Continuous innovation. } \\
\text { The following items of analysing were also highlighted: } \\
\text { culture, leadership, people, processes, tools and } \\
\text { techniques, training, services, capturing ideas, managing } \\
\text { ideas, strategic planning and metrics. }\end{array}$ \\
\hline OVO, 2010 & $\begin{array}{l}\text { Innovation Maturity } \\
\text { Model }\end{array}$ & $\begin{array}{l}\text { Four levels of innovative maturity have been distinguished } \\
\text { in the model: novice, apprentice, journeyman, master, and } \\
\text { five areas in which the analysis is carried out: strategy, } \\
\text { people, methods, founding, measures. }\end{array}$ \\
\hline INPAQT, 2010 & $\begin{array}{l}\text { INPAQT Innovation } \\
\text { Capability Maturity } \\
\text { Model }\end{array}$ & $\begin{array}{l}\text { Five levels of innovative maturity were distinguished: } \\
\text { creativity, collaborative customer centered, business case- } \\
\text { driven, integrated innovation management, co-innovation. } \\
\text { In addition, each of the levels has been assigned the areas } \\
\text { of analysis: } \\
\text { level 1) opportunity analysis, idea generation, idea } \\
\text { management, } \\
\text { level 2) stakeholder analysis, value proposition, } \\
\text { competence group analysis, } \\
\text { level 3) risk analysis, cost-benefit analysis, business case, } \\
\text { level 4) portfolio management, road-mapping, business } \\
\text { strategy, } \\
\text { level 5) entrepreneurial innovation, strategic alliance } \\
\text { management, supply chain management. }\end{array}$ \\
\hline $\begin{array}{l}\text { Praveen Grupta } \\
\text { Accelper } \\
\text { Consulting, 2010 }\end{array}$ & $\begin{array}{l}\text { Business Innovation } \\
\text { Maturity Model } \\
\text { (BIMM) }\end{array}$ & $\begin{array}{l}\text { This model includes five levels of innovation maturity: } \\
\text { sporadic innovations, idea innovations, managed } \\
\text { innovations, nurtured innovations, sustained innovations. }\end{array}$ \\
\hline Howard, 2010 & $\begin{array}{l}\text { Excellence } \\
\text { in Innovation } \\
\text { Framework (EiI) }\end{array}$ & $\begin{array}{l}\text { The model has five levels of maturity: commitment, } \\
\text { putting a process in place, monitoring activity, SMART } \\
\text { goals and improving performance, and continuously } \\
\text { improving performance and seven areas of analysis: } \\
\text { collaboration, environment, finance, knowledge, senior } \\
\text { management, risk, and staff. }\end{array}$ \\
\hline $\begin{array}{l}\text { Funchall, } \\
\text { Herselman and } \\
\text { Greunen, } 2011\end{array}$ & $\begin{array}{l}\text { People innovation } \\
\text { capability maturity } \\
\text { model }\end{array}$ & $\begin{array}{l}\text { The model distinguishes five levels of maturity, which } \\
\text { are: random, emerging, specified, measurable, aligned and } \\
\text { three areas of analysis: people, innovation and capability. }\end{array}$ \\
\hline
\end{tabular}




\begin{tabular}{|c|c|c|}
\hline 1 & 2 & 3 \\
\hline $\begin{array}{l}\text { Müller- } \\
\text {-Prothmann, } \\
\text { Stein, } 2011\end{array}$ & $\begin{array}{l}\mathrm{I}^{2} \mathrm{MM}-\text { Integrated } \\
\text { Innovation Maturity } \\
\text { Model }\end{array}$ & $\begin{array}{l}\text { The model consists of five levels of maturity. The } \\
\text { following process areas are analysed: Quality } \\
\text { Management, Ideation and Product Development, } \\
\text { Requirements Engineering, Innovation Management. }\end{array}$ \\
\hline $\begin{array}{l}\text { Enkell, Bell, } \\
\text { Hogenkamp, } \\
2011\end{array}$ & $\begin{array}{l}\text { Open Innovation } \\
\text { Maturity Framework }\end{array}$ & $\begin{array}{l}\text { The model consists of three elements: climate for } \\
\text { innovation, partnership capacity, internal processes and } \\
\text { five levels of maturity: initial / arbitrary, repeatable, } \\
\text { defined, management, optimization and the following } \\
\text { stages. }\end{array}$ \\
\hline Zaleśna, 2013 & $\begin{array}{l}\text { Maturation model } \\
\text { for innovation } \\
\text { management }\end{array}$ & $\begin{array}{l}\text { The model consists of five stages. } \\
\text { 1. A non-innovative company, not thinking about new } \\
\text { products. } \\
\text { 2. Awareness of the need for change. Interest in } \\
\text { innovation. No planned activities. } \\
\text { 3. Openness of owners to innovation. Brainstorming and } \\
\text { other creativity techniques. Seeing clients as a source of } \\
\text { ideas. } \\
\text { 4. First innovative projects. Cooperation with external } \\
\text { organizations. Learning to be an innovative company. } \\
\text { 5. A mature innovative company. Many innovative } \\
\text { projects. A continuous stream of innovation. }\end{array}$ \\
\hline Mudholkar, 2014 & $\begin{array}{l}\text { A Supply Chain } \\
\text { Innovation Maturity } \\
\text { Model }\end{array}$ & $\begin{array}{l}\text { There are three levels of maturity: reactive, structured, } \\
\text { control and continuous improving. }\end{array}$ \\
\hline $\begin{array}{l}\text { Corsic, Neau, } \\
2015\end{array}$ & $\begin{array}{l}\text { Innovation } \\
\text { Capability Maturity } \\
\text { Model }\end{array}$ & The authors distinguished five levels of innovative maturity. \\
\hline $\begin{array}{l}\text { Raffai, Szikszai, } \\
2015\end{array}$ & $\begin{array}{l}\text { Innovation } \\
\text { Capability Maturity } \\
\text { Model }\end{array}$ & $\begin{array}{l}\text { There are five levels of maturity that have not been named } \\
\text { and five areas of analysis, which are: market knowledge, } \\
\text { training, managing possibilities, guest orientation, } \\
\text { rationality. }\end{array}$ \\
\hline Hüsig, 2015 & $\begin{array}{l}\text { Computer Aided } \\
\text { Innovation Maturity } \\
\text { Model }\end{array}$ & $\begin{array}{l}\text { Five stages were distinguished: standard IT tools; focused } \\
\text { CAI tools, Integrated CAI systems, Enterprise CAI and } \\
\text { Open CAI } 2.0 \text {; Holistic CAI 2.0. solutions. }\end{array}$ \\
\hline $\begin{array}{l}\text { Cukier, Kon and } \\
\text { Lyons, } 2016\end{array}$ & $\begin{array}{l}\text { Startup Ecosystem } \\
\text { Maturity Model }\end{array}$ & $\begin{array}{l}\text { The authors distinguished in this model four levels of } \\
\text { maturity: nascent, evolving, mature, self-sustainable and } \\
\text { eight areas of analysis: exit strategies, entrepreneurship } \\
\text { in universities, angel funding, culture values for } \\
\text { entrepreneurship, specialized media, ecosystem data and } \\
\text { research, ecosystem generations, events. }\end{array}$ \\
\hline $\begin{array}{l}\text { Stahl, Obach, } \\
\text { Yaghmaei, } \\
\text { Ikonen, } \\
\text { Chatfield and } \\
\text { Brem, } 2017\end{array}$ & $\begin{array}{l}\text { Responsible } \\
\text { Research and } \\
\text { Innovation (RRI) } \\
\text { Maturity Model }\end{array}$ & $\begin{array}{l}\text { In this model five levels of maturity were distinguished, } \\
\text { which are: unaware, exploratory/reactive, defined, } \\
\text { proactive, strategic and three areas of analysis: purpose } \\
\text { (motivation), process (activities undertaken), product } \\
\text { (outcomes). }\end{array}$ \\
\hline
\end{tabular}


Table 1, cont.

\begin{tabular}{|c|c|c|}
\hline 1 & 2 & 3 \\
\hline Arends, 2018 & $\begin{array}{l}\text { Firm-level } \\
\text { Innovation } \\
\text { Capability Maturity } \\
\text { Model }\end{array}$ & $\begin{array}{l}\text { This model distinguished five levels of maturity, which } \\
\text { are: ad-hoc, low, intermediate, high, excellent and six } \\
\text { areas of analysis: vision and strategy, value network, } \\
\text { process and governance results and feedback, resources, } \\
\text { culture. }\end{array}$ \\
\hline Bessiti, 2018 & $\begin{array}{l}\text { Innovation Maturity } \\
\text { Matrix }\end{array}$ & $\begin{array}{l}\text { There are five levels of maturity, which are: awareness, } \\
\text { defined, limited, manager, sustained and three areas of } \\
\text { analysis: knowledge scale, actor scale, context scale. }\end{array}$ \\
\hline Demir, 2018 & $\begin{array}{l}\text { Strategic } \\
\text { Management } \\
\text { Maturity Model } \\
\text { for Continuous } \\
\text { Innovation }\end{array}$ & $\begin{array}{l}\text { There are six levels of maturity: undefined, initial, } \\
\text { planned, performer, optimized, excellent and seven areas } \\
\text { of analysis: leadership, planning and executing, process } \\
\text { and tools, structure and model, people and culture, } \\
\text { performance management, innovation. }\end{array}$ \\
\hline Planview & $\begin{array}{l}\text { Innovation } \\
\text { Management } \\
\text { Maturity Model }\end{array}$ & $\begin{array}{l}\text { The model is based on five maturity levels and four } \\
\text { dimensions: strategy, people, processes, and tools. }\end{array}$ \\
\hline $\begin{array}{l}\text { PDMA, Tim } \\
\text { Foundation }\end{array}$ & $\begin{array}{l}\text { The Innovation } \\
\text { Maturity Model }\end{array}$ & $\begin{array}{l}\text { The model includes five levels of maturity: investigation, } \\
\text { implementation, ability, efficiency, perfection. }\end{array}$ \\
\hline IRDG & $\begin{array}{l}\text { Innovation } \\
\text { Capability Maturity } \\
\text { Model (ICMM) }\end{array}$ & $\begin{array}{l}\text { This model differentiates between the five levels of } \\
\text { innovation maturity which are: seeding, championing, } \\
\text { managing, strategizing, and venturing. }\end{array}$ \\
\hline Gartner Group & $\begin{array}{l}\text { Maturity Model } \\
\text { for Innovation } \\
\text { Management }\end{array}$ & $\begin{array}{l}\text { The model distinguishes five levels of maturity and six } \\
\text { dimensions of innovation management. Maturity levels: } \\
\text { Reactive Level, Active Level, Defined Level, Performing } \\
\text { Level, Pervasive Level, Dimensions of Innovation } \\
\text { Management: Strategy and Intent, Processes and Practices, } \\
\text { Culture and People, Organization and Infrastructure, } \\
\text { Partnerships and Open Innovation, Innovating How We } \\
\text { Innovate. }\end{array}$ \\
\hline $\begin{array}{l}\text { BERG } \\
\text { Consulting }\end{array}$ & $\begin{array}{l}\text { The Innovation } \\
\text { Maturity Model }\end{array}$ & $\begin{array}{l}\text { The model consists of five levels of maturity: innovative } \\
\text { practices at the entry level, emerging innovative } \\
\text { practices, coordinated practices in the field of innovation, } \\
\text { innovation, innovation in industry }\end{array}$ \\
\hline KPMG & $\begin{array}{l}\text { Innovation Maturity } \\
\text { Model }\end{array}$ & $\begin{array}{l}\text { The model distinguishes five levels of innovative } \\
\text { maturity: a non-innovative company, a low-innovation } \\
\text { company, a novice innovator, an experienced innovator, an } \\
\text { innovation leader. } \\
\text { The model analyzes areas such as innovation activity, } \\
\text { comprehensive investment activity, market and economic } \\
\text { effects, and the scale of innovative activity. }\end{array}$ \\
\hline
\end{tabular}

Source: own elaboration. 
Analysing the data contained in Table 1, it can be seen that the vast majority of the presented models of innovation maturity are models covering five levels of maturity. Two of the presented models are six-level models, and three of them are four-level models, while one of them includes three levels of innovation maturity. In all the models listed in Table 1, the authors pointed to different levels of innovation maturity, from the lowest to the highest ones. The lowest level was generally characterized by the lack of any innovation activity (e.g. Zaleśna, 2013; Essmann, 2009; Williams, 2010), while the highest level was based on the continuous improvement and management of innovation processes (e.g. Zaleśna, 2013; Esterhuizen et al., 2011; KPMG 2014), i.e. the included companies were often referred to as "innovation leaders". The maturity models mentioned above can be indicated as a some kind of maps used to assess the innovation capacity of organizations, including those operating in the IT industry. The basic idea of the presented models is that a higher level of maturity indicates the increased possibilities of managing innovation capacity (Rapaccini, Saccani, Pezzotta, Burger, and Ganz, 2013). Moreover, these models, being a multi-criteria assessment of innovation maturity, also indicate in which areas the organization should make changes in order to be able to move to a higher level of maturity.

\section{Conclusion}

The literature analysis allowed the author to identify twenty-seven existing models of innovative maturity. Analysing these models, it was noticeable that the models of the organization's maturity are tools that present the theory of how the organization's innovative capability is gradually evolving along a predicted, desirable or logical path. Therefore, as noted by Röglinger et al. $(2012$, p. 4) these models are called stage models, growth stage models, or stage theory.

The main goal of innovation maturity models is to outline maturity paths that include the features of each stage of maturity as well as the logical relationships between them. However, when talking about the purposes of the organization's use of maturity models, including innovative maturity models, it is worth mentioning the three basic goals distinguished in the literature, which are: descriptive, prescriptive and comparative (Röglinger, Pöppelbuß, and Becker, 2012). Innovation maturity models serve a descriptive purpose when they can be used to describe current activities. The prescriptive goal is realized when the model provides information on how the organization can achieve the future desired levels of maturity, and also if it shows what improvement measures to implement in order to achieve the desired higher level of innovative maturity. The last of the mentioned goals of using innovative maturity models - the comparative goal - gives the organization the possibility of external or internal comparisons.

It is also worth noting that organizations that are looking for a suitable model of innovative maturity should be aware of the purpose for which they want to apply 
this model. In the case of descriptive application, it seems that most of the existing models of innovation maturity are able to provide information regarding the diagnosis of the organization of its processes in terms of innovation, while referring to the prescriptive aim it is worth noting that not all of the innovation maturity models give specific guidance as to what the organization should do to move to a higher level of innovation maturity.

Summing up the above considerations, it can be said that innovation maturity models are a tool to assess the current state of an organization. By specifying the exact level of innovation maturity of the organization being studied, they also allow to determine the goals that can be achieved in the future by defining priority actions, as well as identifying ways of their implementation and the necessary resources. Therefore it can be concluded that, in addition to identifying the current state of the organization, innovation maturity models also indicate what the organization should do to increase the level of its innovation maturity.

\section{References}

A Maturity Model for Innovation Management. Retrieved 4.08.2019 from https:/www.gartner.com/en/ documents/1621114/overview-a-maturity-model-for-innovation-management

Arends, S. C. (2018). Development of a Firm-level Innovation Capability Maturity Model and Identification of Innovation Archetypes. Retrieved from https://research.tue.nl/en/studentTheses/development-of-a-firm-level-innovation-capability-maturity-model-

Aziz, N. A., and Omar, N. A., (2013). Exploring the effect of internet marketing orientation, learning orientation and market orientation on innovativeness and performance: SME (exporters) perspectives. Journal of Business Economics and Management, 14(1), 257-278. DOI: https://doi.org/10.3 846/16111699.2011.645865.

Basterretxea, I., and Martinez, R., (2012). Impact of management and innovation capabilities on performance: are cooperatives different? Annals of Public and Cooperative Economics, 83(3), 357-381. DOI: $10.1111 / \mathrm{j} .1467-8292.2012 .00467 . x$.

Batko K., (2017). Zarys koncepcji dynamicznych zdolności analitycznych organizacji w budowaniu przewagi konkurencyjnej. Informatyka Ekonomiczna, 1(43), 9-20. DOI: 10.15611/ie.2017.1.01.

Battista, C., and Schiraldi, M. M. (2013). The logistic maturity model: Application to a fashion company. International Journal of Engineering Business Management, (5), 1-11. DOI: https://doi. org/10.5772/56838.

Berg, P., Leinonen, M., Leivo, V., and Pihlajamaa, J. (2002). Assessment of the quality and maturity level of R\&D, International Journal of Production Economics, 78(1), 29-35.

Berg, R., The innovation maturity model. Retrieved 20.05.2017 from http://bergconsulting.com.au/_literature_144915/Innovation_Maturity_Model.

Birchall, D., and Tovstiga, G. (2005). Capabilities for strategic advantage: Eading through technological innovation. Basingstoke: Palgrave Macmillan. ISBN 9781403945020.

Blommerde, T., and Lynch, P. (2016). A maturity matrix for assessing service innovation capability. Retrieved from http://repository.wit.ie/3186/1/A\%20Maturity $\% 20$ Matrix $\% 20$ for $\% 20$ Assessing $\% 20$ Service\%20Innovation\%20Capability.pdf

Borch, O. J., and Madsen, E. L. (2007). Dynamic capabilities facilitating innovative strategies in SMEs, International Journal Technoentrepreneurship, 1(1), 109-125. DOI: https://doi.org/10.1504/ IJTE.2007.014731. 
Breznik, L., and Lahovnik, M. (2014). Renewing the resource base in line with the dynamic capabilities view. Journal of East European Management Studies, 19(4), 453-485. DOI 10.1688/JEEMS2014-04-Breznik.

Brzeziński, M. (2001). Innowacyjne dylematy przyszłości. In M. Brzeziński, (Ed.). Zarządzanie innowacjami technicznymi i organizacyjnymi, (pp. 317-330) Warszawa: Difin.

Calantone, R. J., Cavusgill, T. S., and Zhao, Y. (2002). Learning orientation, firm innovation capability and firm performance. Industrial Marketing Management, (31), 515-524.

Campos, C., Chalmeta, R., Grangel, R., and Poler, R. (2013). Maturity model for interoperability potential measurement, Information Systems Management, 30(3), 218-234. DOI: https://doi.org/10. 1080/10580530.2013.794630.

Chow, I. H. S., and Gong, J. (2010). The linkage of HRM and knowledge-related performance in China's technology-intensive industries. The International Journal of Human Resource Management, 21(8), 1289-1306. DOI: https://doi.org/10.1080/09585192.2010.483854.

Cooke-Davies, T. J., and Arzymano, A. (2003). The maturity of project management in different industries: An investigation into variations between project management models. International Journal of Project Management, (21), 471-478. DOI: 10.1016/S0263-7863(02)00084-4.

Corsi, P., and Neau, E. (2015). Innovation Capability Maturity Model, John Wiley \& Sons.

Cukier, D., Kon, F., and Lyons, T. S. (2016). Software Startup Ecosystems Evolution. The New York City Case Study (Published at the 2nd International Workshop on Software Startups, IEEE International Technology Management Conference, Trondheim). Retrieved from http://ccsl. ime. usp. br/startups/sites/ccsl. ime. usp. br. startups/files/newyork-ecosystem. Pdf

Demir, F. (2018). A strategic management maturity model for innovation. Technology Innovation Management Review, 8(11), 13-21. Retrieved from https://timreview.ca/article/1196.

Dodgson, M., Gann, D., and Salter, A. (2008). The Management of Technological Innovation: Strategy and Practice (2nd ed.). New York: Oxford.

Eisenhardt, K. M., and Martin, J. K., (2000). Dynamic capabilities: What are they?, Strategic Management Journal, (21), 1005-1121. DOI: https://doi.org/10.1002/1097-0266(200010/11)21:10/11< 1105:: AID-SMJ133>3.0.CO;2-E.

El Bassiti, L. (2018). Multi-dimensional view of innovation performance from knowledge dynamics to maturity matrix. Management Dynamics in the Knowledge Economy, 6(1), 67-85. DOI 10.25019/ MDKE/6.1.04.

Enkell, E., Bell, J., and Hogenkamp, H. (2011). Open Innovation maturity framework. International Journal of Innovation Management, 15(6), 1161-1189, DOI: 10.1142/S1363919611003696.

Essmann, H., and du Preez, N. (2009). An innovation capability maturity model - development and initial application, World Academy of Science. Engineering and Technology International Journal of Social, Behavioral, Educational, Economic, Business and Industrial Engineering, 3(5), 382-393.

Essmann, H. E. (2009). Toward innovation capability maturity. PhD thesis. Stellenbosch: Stellenbosch University. (Unpublished).

Esterhuizen, D., Schutte, C. S. L., and du Toit, A. S. A. (2011). Enhancing innovation capability maturity through knowledge conversion. Acta Commercii, V11(1), 211-231. DOI:10.4102/ac.v11i1.162.

Farrukh, C., Fraser, P., and Gregory, M. (2003). Development of a structured approach to assessing practice in product development collaborations (Proceedings of the Institution of Mechanical Engineers. Part B). Journal of Engineering Manufacture, 217(8), 1131-1144. DOI: https://doi. org/10.1177/095440540321700810.

Fraser, P., Moultrie, J., and Gregory, M. (2002). The use of maturity models/grids as a tool in assessing product development capability (Proceedings of the IEEE International Engineering Management Conference, Cambridge, UK, August 18-20). IEEE Engineering Management Society, Piscataway, 1, 244-249. DOI: 10.1109/IEMC.2002.1038431. 
Funchall, D., Herselman, M., and van Greunen D. (2011). Supporting technological SMMEs through a new maturity model (PICaMM) in South Africa. Information Society Journal: Russia. Retrieved from https://www.researchgate.net/publication/277166166

Gajdzik, B. (2012). Pracownik wiedzy inicjatorem zmian w przedsiębiorstwie. In R. Knosala (Ed.), Innowacje w zarządzaniu i inżynierii produkcji (pp. 913-924), Opole: Oficyna Wydawnicza Polskiego Towarzystwa Zarządzania Produkcją.

Grupta Accelper Consulting. Business innovation maturity model. Retrieved 3.08.2019 from http:// www.managementexchange.com/sites/default/files/media/posts/documents/Brinnovation\%20Maturity\%20Model_020110.pdf

Guan, J., and Ma, N. (2003). Innovative capability and export performance of Chinese firms. Technovation, 23(9), 737-747. DOI: https://doi.org/10.1016/S0166-4972(02)00013-5.

Hamel, G. (2006). The why, what, and how of management innovation. Harvard Business Review, 84(2), $72-84$.

Hogan, S. J., Soutar G. N., McColl-Kennedy, J. R., and Sweeney, J.C. (2011). Reconceptualizing professional service firm innovation capability: Scale development. Industrial Marketing Management, (40), 1264-1273. DOI:10.1016/j.indmarman.2011.10.002.

Howard, J. (2010). Competent to Innovate: An Approach to Personal Development to Improve Innovation Competency in SME's, 5th European Conference on Innovation and Entrepreneurship, Athens.

Hurmelinna-Laukkanen, P., Sainio, L.-M., and Jauhiainen T., (2008). Appropriability regime for radical and incremental innovations. R\&D Management, 38(3), 278-289. DOI: https://doi.org/10.1111/ j.1467-9310.2008.00512.x-i1.

Hüsig, S., (2015). A conceptual model of the revised CAI-NPD-Systems Maturity. Engineering Management Research, 4(2), 9-19. DOI: 10.5539/emr.v4n2p9.

INPAQT. (2010). INPAQT Innovation Capability Maturity Model. Retrieved 1.05.2017 from www. inpaqt.nl

Introducing the innovation management maturity model. Retrieved 3.08.2019 from https://www2.planview.com/im3/?0/1-1/1-1/1-1/1-1/

IRDG. Innovation capability maturity model (ICMM): Building organisational innovation processes. Retrieved 4.08.2019 from http://www.irdg.ie/wp-content/uploads/2015/03/Innovation-Capability-Maturity-Model-by-Darrell-Mann.pdf

KPMG. Dojrzałość innowacyjna przedsiębiorstw w Polsce. Retrieved 4.08.2019 from http://kpmglegal.pl/wp-content/uploads/2014/07/Dojrzalosc-innowacyjna-przedsiebiorstw-w-Polsce-KPMG2014.pdf

Kwak, Y. H., and Ibbs, C. W. (2002). Project management process maturity (PM2) model. Journal of Management in Engineering, 18(3), 150-155. DOI:10.1061/(ASCE)0742-597X(2002)18:3(150).

Lachniewicz, S., Łuczka, and T., Stawasz, E. (2010). Znaczenie i obszary badań nad innowacyjnością i konkurencyjnością małych i średnich przedsiębiorstw w Polsce. Zeszyty Naukowe Politechniki Łódzkiej, 46(1091), 5-16.

Lawson, B., and Samson, D. (2001). Developing innovation capability in organisations: A dynamic capabilities approach. International Journal of Innovation Management, (5), 377-400. DOI: https:// doi.org/10.1142/S1363919601000427.

Liao, J., Kickul, J. R., and Ha, M. (2009). Organizational dynamic capability and innovation: An empirical examination of Internet firms. Journal of Small Business Management, 47(3), 263-286. DOI: https://doi.org/10.1111/j.1540-627X.2009.00271.x.

Lockamy, III A., and McCormack, K. (2004). The development of a supply chain management process maturity model using the concepts of business process orientation. Supply Chain Management: An International Journal, 9(4), 272-278. 
Macchi, M., and Fumagalli, L. (2013), A maintenance maturity assessment method for the manufacturing industry. Journal of Quality in Maintenance Engineering, 19(3), 295-315. DOI: https://doi. org/10.1108/JQME-05-2013-0027.

Mir, M., Casadesus, M., and Petnji, L. H. (2016). The impact of standardized innovation management systems on innovation capability and business performance: An empirical study. Journal of Engineering and Technology Management, (41), 26-44. DOI: 10.1016/j.jengtecman.2016.06.002.

Mirkowska, Z., (2010), Innowacje i innowacyjna gospodarka, a rolnictwo. Zagadnienia Ekonomiki Rolnej, (4), 122-133.

Mizgajska, H. (2006). Aktywność innowacyjna małych i średnich przedsiębiorstw w Wielkopolsce w latach 2001-2004. Gospodarka Narodowa, (5-6), 53-73.

Morsal, S. A. A. T., Ismail, M. Y., and Osman, M.R. (2009). Developing a self-assessment model to measure QMS maturity in ISO certified manufacturing companies. Journal of Scientific and Industrial Research, 68(5), 349-353.

Mudholkar, A. (2014). A supply chain innovation maturity model: A case study in chemical supply chain (Research Report: MISI-2014-2). Retrieved from https://dspace.mit.edu/handle/ 1721.1/102057

Müller-Prothmann, T., and Stein, A. (2011). I'MM - Integrated Innovation Maturity Model for Lean Assessment of Innovation Capability (XXII ISPIM Conference 2011: Sustainability in Innovation). Retrieved from https://ssrn.com/abstract=1868223

Neely, A., Filippini, R., Forza, C., Vinelli, A., and Hii, J. (2001). A framework for analysing business performance, firm innovation and related contextual factors: Perceptions of managers and policy makers in two European regions. Integrated Manufacturing Systems, 12(2), 114-124. DOI: 10.1108/09576060110384307.

Niedzielski, P. (2005). Rodzaje innowacji. In K. B., Matusiak, Innowacje i transfer technologii - Stownik pojęć, PARP.

Niemi, P., Huiskonen, J., and Karkkainen, H. (2009). Understanding the knowledge accumulation process - Implications for the adoption of inventory management techniques. International Journal of Production Economics, (118), 160-167. DOI: https://doi.org/10.1016/j.ijpe.2008.08.028.

O'Connor, G. C., and Ayers, A. D. (2005). Building a radical innovation competency. Research - Technology Management, 48(1), 22-31. DOI: https://doi.org/10.1080/08956308.2005.11657292.

Ormazábal, M., and Sarriegi, J. M., (2013). Environmental management evolution through maturity states. Dirección y Organización, (49), 17-26. DOI: https://doi.org/10.1177/1086026615623060.

Patalas-Maliszewska, J., and Kłos, S. (2013). Zdolność innowacyjna polskich małych i średnich przedsiębiorstw, E-mentor, 3(50). Retrieved from http://www.e-mentor.edu.pl/artykul/index/numer/50/ id $/ 1027$

Paulk, M. C., Curtis, B., Chrissis, M. B., and Weber, C. V. (1993). Capability maturity model, version 1.1., IEEE Software, 10(4), 18-27.

PRTM. (2007). Innovation maturity model. Retrieved 3.05.2017 from http://innovationmanagement.se/ wp-content/uploads/pdf/Roadmap_PRTM.pdf

Raffai, C. (2015). Innovation in rural tourism: A model for Hungarian accommodation providers. Management \& Marketing Challenges for the Knowledge Society, 8(4), 747-766.

Raffai, C., and Szikszai Sz. (2015). Understanding innovation capability maturity in rural tourism. Pannon Management Review, 4(4), 9-31.

Rapaccini, M., Saccani, N., Pezzotta, G., Burger, T., and Ganz, W., (2013). Service development in product-service systems: A maturity model. The Service Industries Journal, 33(3-4), 300-319. DOI: http://dx.doi.org/10.1080/02642069.2013.747513.

Röglinger, M., Pöppelbuß, J., and Becker, J. (2012). Maturity models in business process management. Business Process Management Journal, 18(2), 328-346. DOI:10.1108/14637151211225225. 
Saunila, M. (2016). Performance measurement approach for innovation capability in SMEs. International Journal of Productivity and Performance Management, 65(2), 162-176. DOI: https://doi. org/10.1108/IJPPM-08-2014-0123.

Schumpeter, J. (1934). The theory of economic development, Cambridge: HBR Press.

Stahl, B., Obach, M., Yaghmaei, Ikonen, V., Chatfield, K., and Brem, A., (2017). The responsible research and innovation (RRI) maturity model: Linking theory and practice, Sustainability, 9 (1036). DOI: $10.3390 / \mathrm{su} 9061036$.

Stanisławski R., (2013). Wpływ dynamicznych zdolności innowacyjnych na kształtowanie przewagi konkurencyjnej małych i średnich przedsiębiorstw w Polsce. Organizacja i Kierowanie, 4(157), 119-139.

Stawasz, E., (2012). Innovation capacity of enterprises - Selected issues, Acta Universitatis Lodziensis Folia Oeconomica, (276), 107-121.

Stawasz, E., (2014). Dynamiczna zdolność innowacyjna - wybrane zagadnienia. Acta Universitatis Lodziensis Folia Oeconomica, 4(305), 97-105.

Teece, D. J., Pisano, G., and Shuen, A. (1997). Dynamic capabilities and strategic management. Strategic Management Journal, 18(7), 509-534. DOI: https://doi.org/10.1002/(SICI)10970266(199708)18:7<509::AID-SMJ882>3.0.CO;2-Z.

Teece, D. J. (2007). Explicating dynamic capabilities: The nature and microfoundations of (sustainable) enterprise performance. Strategic Management Journal, 28(13), 1319-1350. DOI: https:// doi.org/10.1002/smj.640.

Think for a Change (2009). Innovation maturity model. Retrieved 1.05.2017 from http://www.thinkforachange.com/innovation-management-artifacts/attachment/im2-innovation-maturity-model/?doing_wp_cron=1496221776.4479970932006835937500

Tim Foundation, PDMA. The innovation maturity model. Retrieved 20.07.2019 from http://timfoundation.org/wp-content/uploads/2015/03/1.0.-Innovation-Maturity-Model-Management-Summary-20150310.pdf

Tsai, M. T., and Tsai, C. L. (2010). Innovation capability and performance in Taiwanese 80 science parks: Exploring the moderating effects of industrial clusters fabric. The International Journal of Organizational Innovation, 2(4), 80-103.

Wang, C. L., and Ahmed, P. K., (2007). Dynamic capabilities: A review and research agenda. International Journal of Management Reviews, 9(1), 31-51. DOI: https://doi.org/10.1111/j.14682370.2007.00201.x.

Wendler, R. (2012). The maturity of maturity model research: A systematic mapping study. Information and Software Technology, 54(12), 1317-1339. DOI:10.1016/j.infsof.2012.07.007.

Zahra, S. A., and George, G. (2002). Absorptive capacity: A review, reconceptualization, and extension. Academy of Management Review, (2), 185-203. DOI: htps://doi.org/10.5465/AMR.2002.6587995.

Zaleśna, A. (2013). Innowacyjność w małych firmach - propozycja modelu dojrzewania do zarządzania innowacjami. In W. Harasim (Ed.), Człowiek i organizacja XXI wieku, Warszawa: Wyższa Szkoła Promocji.

Zhang, J. A., Garrett-Jones, S., and Szeto, R. (2013). Innovation capability and market performance: The moderating effect of industry dynamism. International Journal of Innovation Management, 17( 2). DOI https://doi.org/10.1142/S1363919613500047.

Żołnierski, A. (2005). Potencjat innowacyjny polskich małych i średniej wielkości przedsiębiorstw. Warszawa: Polska Agencja Rozwoju Przedsiębiorczości. ISBN 83-60009-07-4. 